J.Biol.Educ. 8 (2) (2019)

\title{
Journal of Biology Education
}

UNNES

http://journal.unnes.ac.id/sju/index.php/ujbe

\section{Students Worksheet Based on 7E Learning Cycle: Strategies to Improve Activities and Understanding the Concept of Excretion System in MA}

\author{
Avita Rukmana $^{1 凶}$, Siti Alimah ${ }^{1}$
}

Biology Department, FMIPA, Universitas Negeri Semarang, Indonesia

\begin{tabular}{l} 
Article info \\
\hline History Article: \\
Received : June 2019 \\
Accepted : August 2019 \\
Published: August 2019 \\
\hline Keywords: \\
students worksheets based \\
on 7 E learning cycle, \\
activity, understanding \\
the concept of excretory \\
system
\end{tabular}

\begin{abstract}
This study aims to determine the effect of students worksheets of 7E learning cycle on activities and understanding the concept of excretion systems at MAN 1 Jepara. The research method used was preexperimental design with one shot case study. Population of this research was all the students of XI class at MAN 1 Jepara with the samples were XI MIPA 2 and XI MIPA 3 which were taken by purposive sampling. Research data in the form of student activities taken with an observation sheet and understanding the concepts taken with a test. Student activity data were analyzed descriptively quantitatively while understanding the concepts was analyzed by Wilcoxon and N-gain. The results of the study show that the average activity value of XI MIPA 2 students is $88.99 \%$ and XI MIPA 3 is $88.63 \%$ with the criteria of both classes were very high. The average results of conceptual understanding of students of class XI MIPA 2 is 78.67 with classical completeness is $87.18 \%$ while class XI MIPA 3 is 81.73 with classical completeness of $91.89 \%$. The results of the analysis using the Wilcoxon show that the sig value. $0,000<0,05$, means that there are significant differences between the results of the pretest before the application of student worksheet based on 7E learning cycle and posttest results after the application of student worksheet based on 7E learning cycle. The results of the N-gain test showed an increase in understanding of concepts in class XI MIPA 2 and XI MIPA 3 of 0.565 and 0.588 with medium criteria. Based on the results of the study it can be concluded that learning using the students worksheet based on $7 \mathrm{E}$ learning cycle influences the activity and understanding of the excretion system concept of the XI grade students of MAN 1 Jepara.
\end{abstract}

\footnotetext{
${ }^{\square}$ Correspondence :

D6 Building Lt. 1 J1 Raya Sekaran Gunungpati Semarang

E-mail: avitarukmana97@gmail.com
} 


\section{INTRODUCTION}

Material of excretion systems in humans are biological material that is concrete but for the process can not be directly sensed, because the study covers the physiological processes that occur in human body. Excretion system is one concept that is quite difficult because there are many elements of memorization, too many terms, and several other factors (Achmad et al., 2014). The excretory system material in humans is quite complicated because in it is discussed the structure of the organs that play a role in the excretion system as well as the metabolic processes in the body that will be excreted by the excretion organs so that it requires a deeper understanding. There are a number of things that can cause physiological material to be considered as a difficult material, namely the characteristics of the biological material being studied, how the teacher teaches the material that has not made it easier for students to understand the concepts and initial knowledge of students who will study the material (Widarti et al., 2013).

Learning excretion systems in high school have basic competency demands, namely KD 3.9 Analyze the relationship between network structures that make up organs in the excretion system in relation to bioprocesses and functional disturbances that occur in the human excretion system and KD.4.9 display the result of analysis the effect of lifestyle toward organ structure and organs function that cause interference with the excretory system and its connection with technology. Understanding the entire material of excretory system, in the learning process teachers are expected to use media that can support learning process. Media is a communication tool that is channeling messages and can stimulate students' thoughts, feelings, and abilities so that they can encourage the effective and efficient teaching and learning process (Arsyad, 2016). One type of learning media that is often used is students worksheets. The learning media used during the learning process will make the students easy to understand the concepts of the subject matter being studied. The use of good and effective learning media will give maximum results to student learning outcomes (Wena, 2008).

Understanding of concepts is one of the factors that can affect the success of students in learning. Understanding the concept shows that students are not only kneaded to memorize the material but must understand the concept and its implementation. Darmayanti et al., (2013) explained that one of the important teaching goals is to help students understand the main concepts in a subject, not just remembering separate facts. Understanding the concept according to Rizal (2014) not only knows a concept but can connect between one concept and another concept in various situations. Learning must also prioritize the process so that students can develop their own understanding concepts so that the concepts obtained can be long-term memories.

Based on interviews conducted by the researchers toward biology subject teachers in class XI of MAN 1 Jepara, it is known that there are still many students who obtain less grades from KKM (Minimum Completion Criteria) that have been set. Student learning outcomes in the excretion system material for the 2017/2018 are still low or incomplete, which is as much as $48.64 \%$ of students have not reached KKM 75 . This is because students find it difficult to understand the concept of excretion systems, especially humans. The concept of understanding students is low because the concepts are understood not from the results of the discovery process that is built by the students themselves so that the concepts obtained are short-term memory.

The completeness of student learning outcomes can be improved by using teaching materials or worksheets that are appropriate to the needs of the students. Based on the 
observation results, during the learning process, the teacher did not compile their own students worksheets and used students worksheets more commercialized by the publisher to schools. Even though not all students worksheets contents as teaching materials are in accordance with the learning model that will be applied and in accordance with the characteristics of the students being taught. students worksheets used in the school contains a summary of the material, practical instructions and practice exercises that have not trained students to actively compose their own concepts and connect material to everyday life. During the learning process, the teacher reads the material more often and gives them the task of working on the questions on the worksheet, causing students to be less active in learning. As a result, the class becomes monotonous and passive. This can be seen from student activities during the learning process takes place. Students are only limited to listening to the teacher, students are passive if the teacher gives a question, students tend to be passive when conducting discussions, and some students take notes if instructed by the teacher. This lack of learning activities has an impact on the low student learning outcomes.

Based on these problems, it is necessary to have worksheets that are able to activate students containing explanations of important stages that make it easier for students to understand the concepts and learning models that are able to activate students and be able to provide students with understanding through the learning cycle concept. The learning cycle model is a constitutionist-based science learning model which knowledge is built based on student thinking. Based on the results of the research by Mirjanah et al., (2017) learning using the learning cycle model invites students to discover concepts in learning on their own and students are actively involved in each stage, in addition, students will carry out activities such as question and answer, discussion, observation, solving problems, give opinions, present in front of the class and conclude. The learning cycle model according to Izzati et al., (2016) can improve student activity and learning outcomes. Susilawati et al., (2014) stated that the learning cycle model influences students' understanding of the concepts and scientific attitudes. The learning model of the 7E learning cycle can facilitate students to discover concepts that are learned by active involvement. The learning cycle model is also able to improve student learning outcome so that the model can be used as one of the bases in preparing students worksheets.

Eisenkraf (2003) developed a learning cycle model for seven people because they obtained, obtained (interest generation), explored (explored), explained (explained), elaborated (elaborated), evaluated (evaluated), and expanded (developed). The learning cycle model has many advantages, namely students to reassess the subject matter that has been previously obtained, giving students motivation to be more active and increase students' curiosity, encourage students to learn what they have shared, give students the opportunity to think, search, find and explain examples of the application of concepts that have been learned, teachers and students begin learning stages that complement each other (Sutrisno et al., 2013).

Learning material for the human excretion system is appropriate if it is supported by using students worksheets based on $7 \mathrm{E}$ learning cycle. This is because the system material explains the process that cannot be directly sensed which requires a more complete understanding delivered with inspection activities, discussions, problem-solving, giving opinions, presenting in front of the class and discussing. This students worksheets is expected to help students get ideas about individuals or groups that make learning more important which will make it easier for students to understand the concepts of the human excretion system. 
Based on the discussion above, the discussion was proposed regarding student worksheets based on 7E learning cycles of activities and understanding of the excretion system concept in MAN 1 Jepara. This study aims to determine the effect of students worksheets of 7E learning cycle on activities and understanding the concept of excretion systems at MAN 1 Jepara.

\section{RESEARCH METHODS}

The research method used was pre-experimental design with one shot case study. The population of this research was students of XI MAN 1 Jepara 2018/2019 with samples of class XI MIPA 2 and XI MIPA 3 which were taken by purposive sampling. The independent variable in the form of learning using student worksheets based on $7 \mathrm{E}$ learning cycle while the dependent variable is the activity and comprehension of the excretory system concept.

The type of data collected is in the form of student activity data and students' conceptual understanding. The instruments of data collection consisted of observation sheets of student activities, understanding of concepts from test sheets (pretest and posttest) and students worksheets, learning implementation questionnaires, student response questionnaires and teacher response interview guidelines.

\section{RESULTS AND DISCUSSION}

The students' activities in this study were observed during the learning activities using students worksheets based on 7E learning cycle by observers. Those activities are visual activities, oral activities, writing activities, and mental activities. In this study, students were asked to make a group and work on existing activities in the students worksheets based $7 \mathrm{E}$ learning cycle on human excretion systems. Each student gets a chest number to make it easier for the observer to observe student activities while working on students worksheets based on $7 \mathrm{E}$ learning cycle. Data on the observations of student activities are presented in Figure 1.

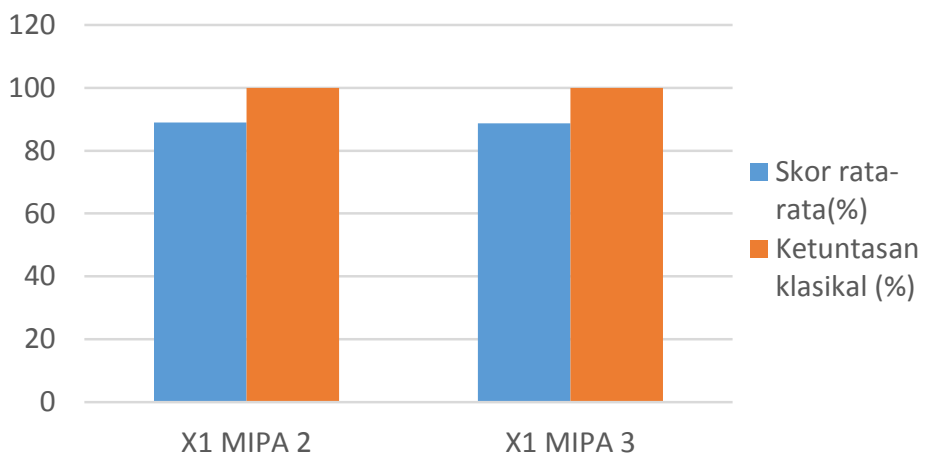

Figure 1. Student activity

Based on the results of the analysis showed that the average percentage of students' activity of class XI MIPA 2 and MIPA 3 was $88.99 \%$ and $88.63 \%$ with very high criteria. The percentage of the level of completeness of activity in classical is $100 \%$ in both classes, which means that classically has achieved the indicator of success. This shows that learning with students worksheets based on 7E learning cycle, students actively interact with teachers and other students as well as students follow the learning process as expected by the teacher. One 
of the things that causes an increase in student activity in students worksheets based on 7E learning cycle is that learning is done in groups. During the learning process students do interaction, cooperate and exchange ideas to discuss existing problems in the students worksheets based $7 \mathrm{E}$ learning cycle. Group learning makes students who are previously passive become active because students are more free to ask questions and exchange opinions about the material of the human excretion system that has not been understood with their group members. The existence of group discussions also makes students active and enthusiasm for learning so that it influences their learning outcomes. In accordance with the opinion of Side $e t$ al., (2013) the method of discussion can help improve student activity and learning outcomes.

Furthermore, to find out the results of student activities based on the observed aspects during the learning activities using students worksheets based on $7 \mathrm{E}$ learning cycle are presented in Figure 2.

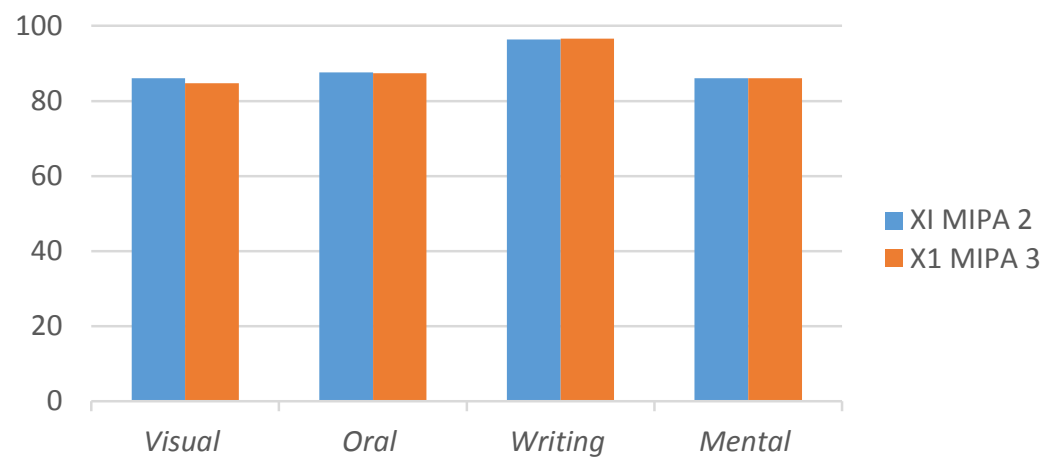

Figure 2. Student activity based on observed aspects

Based on Figure 2 the results show that learning with students worksheets based on 7E learning cycle creates high writing activities followed by the lowest oral activities, mental activities, and visual activities both in class XI MIPA 2 and XI MIPA 3. According to observations in the students worksheets based on 7E learning cycle makes the students happy and interested in learning to use students worksheets based on $7 \mathrm{E}$ learning cycle so that it creates activity in learning. The activity of students was also influenced by students 'interest in students worksheets based on $7 \mathrm{E}$ learning cycle, as seen from the students' questionnaire, namely, students were happy and interested in learning using students worksheets based on 7E learning cycle. This result is reinforced by teacher responses that express interest in using students worksheets based on 7E learning cycle that can increase student activity. This interest is due to more interesting learning and students look more active, enthusiastic in participating compared to learning activities with teacher-centered learning.

The learning activities that make the students active in the highest learning process are writing activities, learning activities using students worksheets based on 7E learning cycle students are given the opportunity to write the results of discussions in turn with their group friends and each member can convey ideas, ideas to build understanding, and practice thinking skills through writing activities so as to create higher activity in both classes. This writing activity will provide learning experiences for students in increasing understanding of the material being studied. Hamalik (2012) explains that training activities provide learning experiences that can help students develop thinking skills and help students learn more effectively. 
Oral activities, learning activities using students worksheets based on 7E learning cycle are conducted with group discussions to answer the questions presented in the students worksheets. During the discussion activities students are given the opportunity to express their opinions, ask questions, and express answers to questions, so students participate actively in discussing answers to questions by expressing their opinions alternately, responding to friends' opinions and asking questions about problems discussed with friends if there are no answers to questions understood. According to Machin (2012) student activity in group, students' ability to express answers, students' ability to develop ideas and answers, students' ability to work together and students' ability to respond to friends' opinions have a positive influence on learning activities. This activity is caused by students using all their potential optimally in the learning process.

Mental activities, in students worksheets based on 7E learning cycle students, are given the opportunity to carry out problem-solving activities presented in the students worksheets. Problems solved by students must be in accordance with the concept and contain relationships between concepts so that students can play an active role in solving a problem presented by exchanging ideas with a group of friends. The problem-solving activity can help students develop thinking skills. Sumiati \& Asra (2007) explain that problem-solving skills require a thought process. If the problem is solved successfully, it means that the students succeed in learning something new.

The lowest activity is visual activities, in the experimental activities by designing a blood screening model in the kidney, then compiling an experimental tool according to the image and writing the data as observed, students actively participate in learning, this is because students are given the opportunity to practice and observe directly, thus triggering students to be more active in doing each step of the activity carried out then observing the results directly. Different from paying attention to friends' explanations during presentations when friends ask questions, answer according to concepts, and respond to friends' explanations, students tend to passively pay attention to friends' explanations, causing visual activities to be low. However, the average difference in each activity did not differ greatly in the two classes.

The activity of students classically fits the criteria very high, but there are still some students who do not increased in each activity. This is due to learning with the students worksheets based on 7E learning cycle that allows some students to depend on group friends when conducting discussions. Another cause is the material has a higher level of difficulty than the previous material, then there are some students who have quiet characteristics and feel less confident so they do not show their ability. Students who have these characters need to be given more attention so that they dare to ask questions and express their opinions because the teacher's role is a facilitator that facilitates students to learn more optimally. The teacher as a facilitator according to the Mosque statement (2009) as one of the elements that plays an important role in carrying out the learning process.

The application of learning using students worksheets based on 7E learning cycle on human excretion system material, in addition to analyzing its influence on student activities, the writer also analyzed its effect on students' conceptual understanding. Understanding the concepts in this study refers to Anderson \& Karthwohl (2002), namely: interpreting, giving examples, classifying, summarizing, concluding, comparing and explaining. Conceptual understanding in this study was measured using the pretest problem to determine the students' initial abilities and posttest questions to determine the level of concept understanding after the learning process using students worksheets based on 7E learning cycle human excretion system 
material. Students are said to have a good understanding of concepts in this study if students are able to classify, explain, compare, conclude and give examples. Test data for understanding students' concepts is presented in Figure 3.

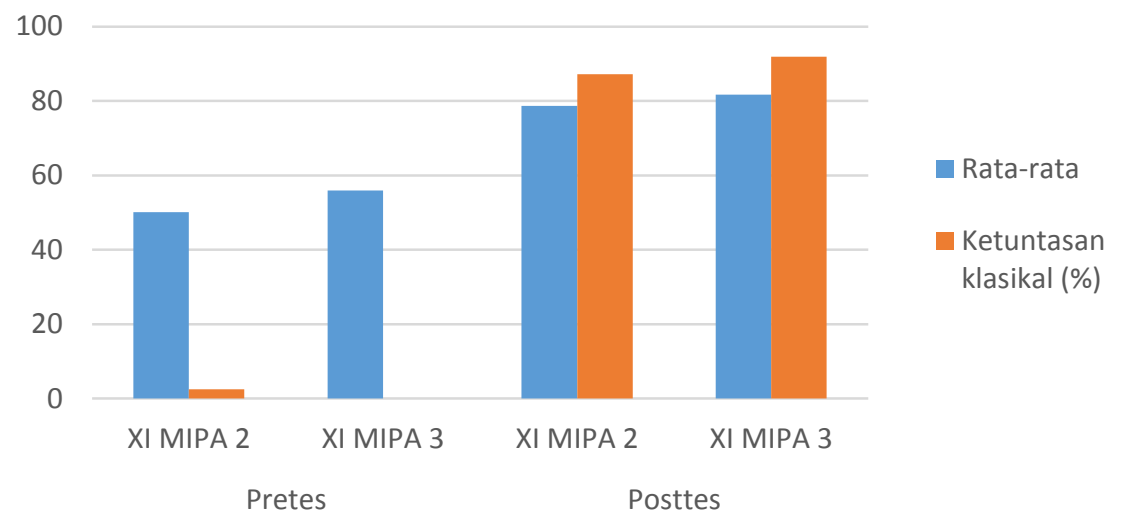

Figure 3. Results of students' pretest and posttest

Based on the analysis of the results of the understanding concept of the pretest before applying learning using students worksheets based on $7 \mathrm{E}$ learning cycle and posttest after applying learning using students worksheets based on 7E learning cycle experienced an increase in both classes. The average results of understanding students' concepts after applying learning using students worksheets based on 7E learning cycle class XI MIPA 2 amounted to 78.67 with $87.18 \%$ classical completeness while class XI MIPA 3 was 81.73 with classical completeness $91.89 \%$. The percentage of classical completeness in class XI MIPA 3 is higher than the percentage of classical completeness of students of class XI MIPA 2. However, the difference in average and classical completeness is not much different. This indicates that the two classes have relatively the same ability to understand concepts.

The results of the pretest and posttest of conceptual understanding on students worksheets learning based on 7E learning cycle of human excretion system material were also analyzed based on the indicator aspects of conceptual understanding. The recapitulation of the question analysis based on indicators of concept understanding is presented in Figure 4.

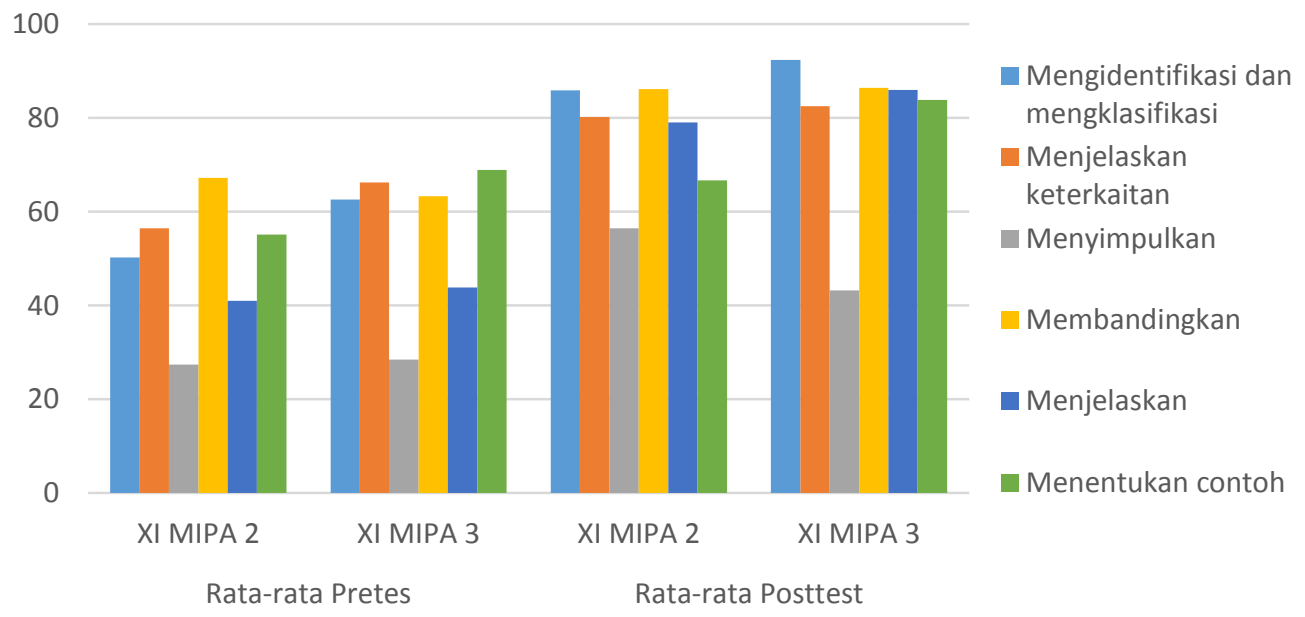

Figure 4 Analysis of pretest and posttest results based on indicators of understanding concepts 
Based on the results of the pretest analysis of the conceptual understanding aspects before applied learning using students worksheets based on 7E learning cycle shows that class XI MIPA 2 questions with indicators comparing the highest answered correctly and class XI MIPA 3 questions with indicators determining the highest example is answered correctly, while indicators are the lowest measure is concluded in both classes. Similar to the results of the posttest analysis of aspects of the conceptual understanding aspect after applying learning using students worksheets based on 7E learning cycle shows that the XI MIPA class 2 questions with indicators comparing the highest answered correctly and the XI MIPA class 3 questions with the highest identification and classification indicators answered correctly, while the questions with indicators conclude in the two lowest classes answered correctly by students. It is also seen during the learning process that takes place, namely when students are asked to identify and classify organs that make up the excretory system, and comparing each process that occurs in the human body, students are able to do it well. However, students find it difficult to conclude the interrelationship of the work processes of excretory organs with everyday phenomena, because students do not understand the concept well, especially when connecting with everyday phenomena. This can be seen from question number 13 concluding the work process of the skin organ if the skin is fearful and tense, question number 17 concludes the relationship of the work process of the skin organ if the skin is injured and question number 18 concludes the working process of the kidney organ that produces urine for drug-free testing. Based on the three questions, only number 18 has been done by students through discussion activities using $7 \mathrm{E}$ learning cycle-based students worksheets so that students who answer incorrectly the least, while questions number 13 and 17 are not discussed by students in learning, but also because of students' low analogy skills. cannot conclude a different case on the same concept. Although the indicator indicators concluded that the low classics completeness XI MIPA 2 and XI MIPA 3 had exceeded the minimum criteria set.

The results of the pretest and posttest were then analyzed using the Wilcoxon. The Wilcoxon test is used because the data are not normally distributed, so the non-parametric statistical test is done, the Wilcoxon test. Based on statistical analysis shows that the Sig. 0,000 $<0.05$ means there were significant differences between the value of pretest before the application of students worksheets based on $7 \mathrm{E}$ learning cycle and posttest results after the application of students worksheets based on 7E learning cycle, so it can be said that learning using students worksheets based on learning cycle had an effect on the learning outcomes of students' understanding of excretory system material. The effect of learning using students worksheets based on $7 \mathrm{E}$ learning cycle on the learning outcomes of students' understanding of concepts in both classes is due to the learning done use the right methods and interesting learning that will make it easier for students to capture the content of the material being studied and can foster student activity in learning so that it creates a pleasant learning atmosphere.

Furthermore, the N-gain test was conducted to see how much the students' understanding of the concept of improvement was measured through the results of the pretest and posttest. The results of the N-gain analysis are shown in Figure 5. 


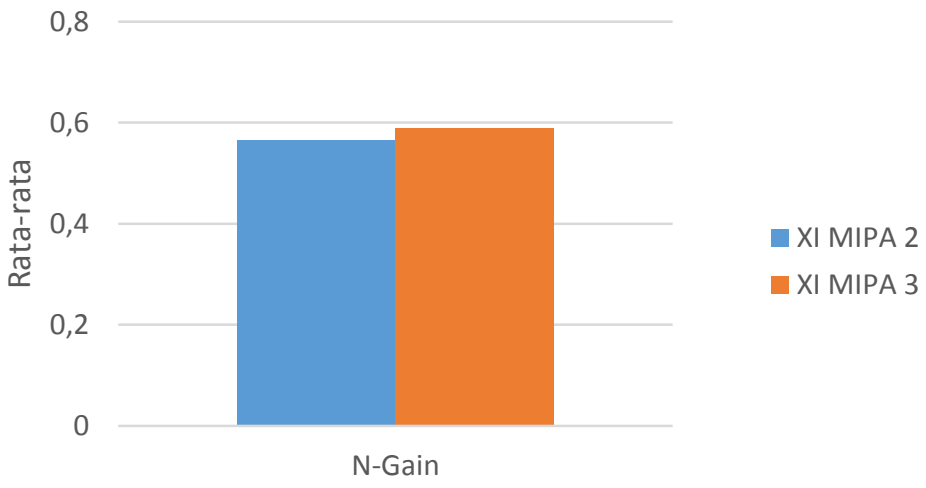

Figure 5. Results of the $\mathrm{N}$-gain value

Based on Figure 5, the results show that the average N-gain value of class XI MIPA 2 and XI MIPA 3 is 0.565 and 0.588 with the medium criteria. An increase in the $\mathrm{N}$-gain value indicates an increase in students' understanding of the concept of human excretion system material. The high level of conceptual understanding of students who are taught using students worksheets based on $7 \mathrm{E}$ learning cycle because students are given the opportunity to explore and construct concepts that are learned independently in each learning step so that students are more aware of the material being studied as evidenced by an increase in students' conceptual understanding.

Improving students' conceptual understanding is also due to the achievement of the implementation of teacher and student learning using students worksheets based on 7E learning cycle. Enhancing students' understanding of concepts is also supported by the results of observational analysis of the implementation of the teacher and student learning which shows that the two experimental classes have an average level of achievement of learning almost the same. The average implementation of teachers in learning using students worksheets based on 7E learning cycle in class XI MIPA 2 and XI MIPA 3 was $92.43 \%$ and $93.18 \%$ with very good categories. This shows that the learning process carried out by the teacher in both classes is done well and almost does all the aspects observed by the observer and in accordance with the learning design that has been made. While the average implementation of students in students worksheets based on 7E learning cycle in class XI MIA 2 and XI MIA 3 was $81.82 \%$ and $82.58 \%$ with very good categories. This shows that the success of students in both classes in the implementation of learning using the students worksheets based on 7E learning cycle is also successful and in accordance with the learning design that has been made. This is in line with the results of research conducted by Tania \& Murni (2017) which states that the implementation of learning by teachers and students is carried out well after the learning cycle learning model has been applied.

Learning using students worksheets based on 7E learning cycle helps students build concepts from simple to application concepts that have been obtained. The concept obtained is obtained from the results of student scores in working on students worksheets based on $7 \mathrm{E}$ learning cycle in groups presented in Figure 6. 


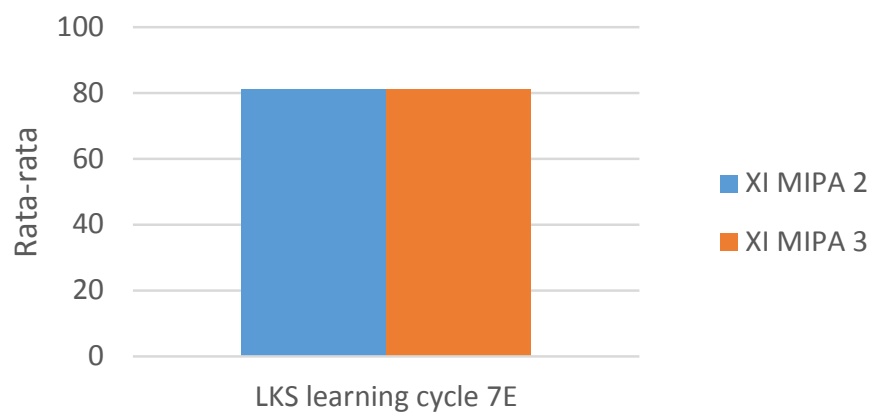

Figure 6. Results of students worksheets based on 7E learning cycle

Based on Figure 6, the results of the two classes have almost the same average score of 81.17 in MIPA 2 and 81.19 in MIPA 3. Learning with students worksheets based on 7E learning cycle has a good influence on students' success in learning, especially within themselves. students have meaningful learning. This is in accordance with meaningful learning theory (meaningful learning) where the process of acquiring knowledge is built by linking new information with existing concepts in students' cognitive. Learning experiences obtained by students in each stage of the students worksheets learning cycle model involve events in real life students so that the information obtained is easier for students to remember and interpret.

Anggraini et al., (2016) states that the implementation of students worksheets based on 7E learning cycle is very practical to be used by students who can help construct knowledge and connect concepts obtained with real life so that learning becomes meaningful. Suyati \& Krispinus (2015) stated that students worksheets learning can improve student learning outcomes and activities as indicated by an increase in learning outcomes from pretest to posttest and the percentage of student activities with active criteria. This is reinforced by the opinion of Celiker (2010) which states that the use of worksheets developed in accordance with constructive theories can improve student academic achievement.

The results of learning to understand the concepts of both experimental classes, in general, can be concluded thoroughly. Classical completeness of the learning outcomes of understanding the concepts of each class reaches more than $75 \%$. The classical completeness calculation is taken based on the percentage of individual completeness towards the whole class. Individual completeness was obtained based on the calculation of the average learning outcomes understanding concepts from the cognitive aspects of the posttest value and the students worksheets value. Overall student mastery learning is presented in Figure 7.

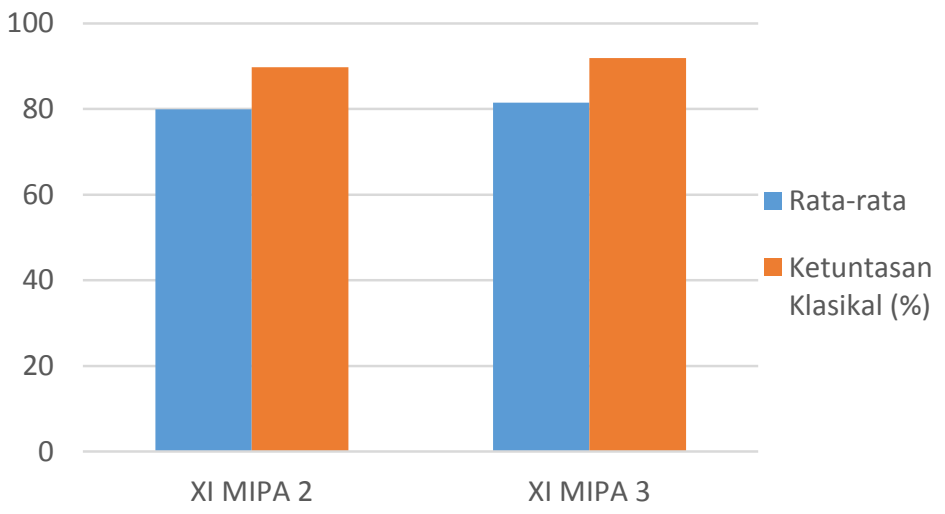

Figure 7. Final grades of students 
Based on Figure 7 it is known that the average completeness of the overall results of learning conceptual understanding of class XI MIPA 2 and MIPA 3 is 79.92 and 81.46. Classical completeness of class XI MIPA 2 and MIPA 3 is $89.74 \%$ and $91.89 \%$. This suggests that overall the two classes have exceeded $75 \%$ classical completeness. Based on the learning outcomes of understanding the concept as a whole it can be concluded that learning using students worksheets based on 7E learning cycle can improve the learning outcomes of students' concept understanding. This is in line with the opinion of Susilawati et al., (2014) which states that there is an influence of students' ability to understand concepts and scientific attitudes after following the 7E learning cycle model, increasing motivation and learning outcomes (Candra \& Achmadi, 2017), and improving learning achievement significantly (Polyiem et al., 2011).

The success of understanding concepts on students is influenced by internal factors and external factors. Internal factors (factors in students) include the level of intelligence, student motivation and interest in participating in learning. Hamalik (2012) explains that psychological aspects in the form of intelligence (level of intelligence) have a large influence on student learning success, then Candra et al., (2017) explains that motivation influences learning outcomes. Another influential factor is the external factor, the student class environment. If the student classroom environment has a positive influence and is not boring, students will like the atmosphere of the class. This is supported by the results of positive responses of students, namely most students stated motivated and interested in learning, liked the classroom atmosphere that applied learning with students worksheets based on 7E learning cycle and did not feel bored if learning using students worksheets based on 7E learning cycle.

Apart from the positive results outlined, in the implementation of this research there were several obstacles faced including learning using students worksheets based on 7E learning cycle giving students the opportunity to work in groups that have been determined by the teacher so that sometimes students tend to do activities that trigger noise, play alone and not paying attention to instructions from the teacher. Another obstacle is managing less time and more energy in planning and implementing learning. Therefore, it requires a more mature plan, good student control, and better management of time so that the learning process can go as expected.

\section{CONCLUSION}

Based on the results of research and discussion it can be concluded that the students worksheet based on 7E learning cycle affects the activity of class XI students of MAN 1 Jepara and students worksheet based on $7 \mathrm{E}$ learning cycle have a significant effect on the understanding of the excretion system concept of class XI students of MAN 1 Jepara.

\section{REFERENCES}

Achmad I., S. Diana, \& A.R Wulan. 2014. Penerapan Learning Class untuk Mendiagnostik Kesulitan Belajar Siswa SMA pada Materi Sistem Ekskresi Manusia. Fomica Education Online, 1(1): 2.

Anderson, L.W. \& D.R. Karthwohl. 2002. A Taxonomy for Learning, Teaching and Assessing; A revision of Blooms Taxonomy of Education Objectives. New York: Addison Wesley Lonman Inc.

Anggraini, W., Y. Anwar, \& K. Madang. 2016. Pengembangan Lembar Kerja Peserta Didik (LKPD) Berbasis Learning Cycle 7E Materi Sistem Sirkulasi pada Manusia untuk Kelas XI SMA. Jurnal Pembelajaran Biologi, 3(1):49-57.

Arsyad, A. 2016. Media Pembelajaran. Jakarta: Raja Grafindo Persada. 
Candra, I.A. \& H.R. Achmadi. 2017. Model Pembelajaran Learning Cycle 7E untuk Meningkatkan Motivasi dan Hasil Belajar Siswa pada Materi Gerak Harmonik Kelas X di SMAN 1 Kejayan. Jurnal Inovasi Pendidikan Fisika (JIPF), 6(3): 83-90.

Celikler D. 2010. The Effect of Worksheets Developed for the Subject of Chemical Compounds on Student Achievement and Permanent Learning: Educational Research Association. The International Journal of Research in Teacher Education 2010, 1(1):42-51.

Darmayanti, N.W.S., Sadia W, Sudiatmika. 2013. Pengaruh Model Colaborative Teamwork Learning terhadap Keterampilan Proses Sains dan Pemahaman Konsep Ditinjau dari Gaya Kognitif. EJournal Program Pascasarjana Universitas Pendidikan Ganesha Program Studi Sains, 3.

Eisenkraft, A. (2003). Expanding the 5E Model A Purposed 7E Model Emphasizes "Transfer Of Learning" And The Importance Of Eliciting Prior Understanding. The Science Teacher Journal, 70(6): 56-71.

Hamalik, O. 2012. Kurikulum dan Pembelajaran. Jakarta:.Bumi Aksara.

Izzati, L.R., Sutopo, \& H.E. Chrisnawati. 2016. Penerapan Model Learning Cycle 7E untuk Meningkatkan Aktivitas dan Hasil Belajar Matematika Kelas Peminatan XI MIPA 3 Semester 2 SMA Negeri 5 Surakarta Tahun Ajaran 2014/2015. Prosiding Seminar Matematika dan Pendidikan Matematika. Solo: Universitas Sebelas Maret.

Majid, A. 2009. Perencanaan Pembelajaran. Bandung: Remaja Rosdakarya

Machin. 2012. Pengaruh Permainan Call Cards terhadap Hasil Belajar dan Aktivitas Pembelajaran Biologi. Jurnal Pendidikan IPA Indonesia, 1(2): 163-167.

Mirjanah, M., S.P. Hastuti, \& D.F. Priyayi. 2017. Peningkatan Aktivitas dan Hasil Belajar Siswa Melalui Penerapan Model Learning Cycle 7e (Lc 7e) pada Pembelajaran Biologi Kelas X Ipa 4 Sma Negeri 1 Bringin Tahun Pelajaran 2016/2017. Varia Pendidikan, 29(1): 18-27.

Polyiem, T., P. Nuangchalerm, \& P. Wongchantra. 2011. Learning Achievement, Science Process Skill, and Moral Reasoning of Ninth Grade Student Learn by 7E Learning Cycle Socioscientific IssueBased Learning. Australian Journal of Basic and Applied Science, 5(10): 257-264.

Rizal, M. 2014. Pengaruh Pembelajaran Inkuiri Terbimbing dengan Multipreresentasi terhadap Keterampilan Proses Sains dan Penguasaan Konsep IPA Siswa SMP. Jurnal Pendidikan Sains, 2(3):159-165.

Side, S., Hardin, \& M. Tanrere. 2013. Penerapan Metode Diskusi Berkelanjutan pada Mata Pelajaran Kimia untuk Meningkatkan Keaktifan dan Hasil Belajar siswa Kelas XI IPA 6 SMA Negeri 11 Makasar. Jurnal Chemica, 14(1):46-56.

Sumiati \& Asra. 2007. Metode Pembelajaan. Bandung: Wacana Prima.

Susilawati, K., P.B. Adnyana, \& I.B.J. Swasta. 2014. Pengaruh Model Siklus Belajar 7E terhadap Pemahaman Konsep Biologi dan Sikap Ilmiah Siswa. E-journal program pasca sarjana Universitas Pendidikan Ganesha, 4.

Sutrisno, W., Sri D., Puguh K. 2013. Pengaruh Model Learning Cycle 7E terhadap Motivasi Belajar Siswa dalam Pembelajaran Biologi. Seminar Nasional IX Pendidikan Biologi. Solo: Universitas Sebelas Maret.

Suyati., K. K. Pukan. 2015. Pengembangan Lembar Kerja Siswa Berbasis "PDEODE" Materi Sistem Pencernaan Manusia. Unnes Journal of Biology Education 4 (1):45-52.

Tania, B. \& Murni. 2017. Penerapan Model Pembelajaran Learning Cycle 5E untuk Meningkatkan Keterampilan Proses Sains Siswa. Jurnal Ilmiah Penelitian dan Pembelajaran Fisika, 3(1): 66-79.

Wena, M. 2008. Strategi Pembelajaran Inovatif Kotemporer Suatu Tinjauan Konseptual Operasional. Jakarta: PT. Bumi Aksara.

Widarti, S., P. Endah, \& P. Widiyaningrum. 2013. Pembelajaran Gallery Walk Berpendekatan Contextual Teaching Learning Materi Sistem Pencernaan di SMA. Unnes Journal of Biology Education, 2(1): 1018. 